\title{
Influence of Home Based Factors on the Academic Performance of Girl Learners from Poverty Stricken Families: A Case of Zimbabwe
}

\author{
Kudzai Chinyoka \\ Great Zimbabwe University, Faculty of Education, \\ Department of Educational Foundations \\ E-mail: chinyokak@gmail.com \\ Narainsamy Naidu \\ Department of Psychology of Education, \\ University of South Africa (UNISA), College of Education \\ E-mail: naidun@unisa.ac.za
}

\section{Doi:10.5901/mjss.2014.v5n6p223}

\begin{abstract}
This article examines the home based factors that influence the academic performance of the girl child from poverty stricken households in Masvingo province, Zimbabwe. With the prevailing economic hardships faced by the majority of the people in Zimbabwe since 1990, the number of girl children living in poverty is continually increasing and it has become a growing issue. A qualitative phenomenological design was used incorporating focus group discussions, interviews and observations as data collection instruments with ten girl children, six parents and four teachers at two secondary schools, one rural and another urban in Masvingo province. The participants comprised girl students doing form three, their parents and also some of their teachers. The study is informed by Bronfenbrenner's ecological theory. This study established that the girl child's academic performance is affected by multiple contexts including family, home, neighbourhood and school. The study concluded that family income, parental level of education, gender, home circumstances, and family size influenced academic achievement of girls in secondary schools. The home circumstances of girls from poor backgrounds were observed to be not conducive to learning because of a lack of lighting, spending much time on domestic chores, having no desk or table to work at, or not having books at home. The girl learners also did not get basic needs met like food, sanitary pads and school fees. Recommendations are that the government should sensitize parents on the need and importance of supporting the education of girls and on the importance of providing for the needs of the girl child. Finally, every effort must be made to ensure that the affected children have stable, preferably home/family based care and adequate social support. Various policies and interventions can help to attenuate poverty's negative influence on child development.
\end{abstract}

Keywords: home-based, poverty, academic performance, ecological, phenomenological, girl child

\section{Background of the Study}

Educators and researchers have long been interested in exploring variables contributing to the quality of academic performance of girl learners. Academic performance is affected by a number of factors including age, gender, geographical belongingness, ethnicity, marital status, socioeconomic status (SES), parents' education level, parental profession, language, income and religious affiliations and school background (Chinyoka and Naidu 2013; Hafiz, Tehsin, Malik, Muhammad and Muhammad, 2013; Hlupo and Tsikira, 2012 Chabaya, Rembe and Wadesango, 2009). Home environment has been recognized as having a lot of influence on academic performance. The family being the first and major agency of socialisation has a great influence and bearing on the development of the child (Threlfall, Seay and Kohl, 2013). Adeyemo (2006) as cited in Ganga and Chinyoka (2010) explained that the child's first place of contact with the world is the family. The child as a result acquires initial education and socialisation from parents and other significant others in the family, thus the parents are indeed the child's first educators.

Children who experience poverty may live in physical environments that offer less stimulation and fewer resources for learning. Constantine (2005) as cited in Brooks-Gunn, Duncan and Aber (2007) examined six communities in the greater Los Angeles, California area, and found that children in high-income communities had access to significantly more books than children in low-income communities did. In fact, she found that in some affluent communities, children had more books in their homes than low socio-economic status (SES) children had in all the school sources combined. 
The lack of support and cognitive stimulation in the children's home environments was found to account for one third to a half of the disadvantages in verbal, reading, and mathematical skills among persistently poor children (Korenman, Miller and Sjaastad, 2005:145). Poverty results in poor home circumstances for learning, and affects the children's physical well-being and ability to learn, is associated with low parental education, and limits the resources for investing in education. According to Yeung, Linver and Brooks-Gunn (2002) as cited in Chinyoka and Naidu (2013) the poor parents may be less able to buy them games, toys, books, computers, and other resources that promote learning, or to provide them with high-quality childcare. They may be living in places that are not safe for outdoor play. All of these challenges in poor communities, considered together with the impact of lower levels of parental education, may result in the children having little or no assistance with their homework, and less motivation to learn. Children from poor economic backgrounds are not afforded the same luxuries and opportunities as those from wealthy backgrounds. This is one reason why differences in vocabulary and reading ability are associated with family income (Chindanya, 2012). Poor families are faced with the direct as well as the indirect consequences of their economic situation, including the lack of resources, and the stress associated with their predicament (Okeke, Nzewi, and Njoku, (2012); Chabaya, Rembe, and Wadesango, (2009).

Given the above, the home environment should be endowed with resources and be conducive to promote learning. At the household level, evidence suggests that girl children from poorer households are generally likely to receive less education.

\section{Theoretical Framework}

This study is informed by Bronfenbrenner's (2008) ecological theory which suggests that a person's surroundings including their home, school, work, church, neighbourhood, culture and government have an influence on the way a child develops (Donald, Lazarus and Lolwana, 2010; Woolley and Kaylor, 2006). This theory looks at learners' development within the context of the system of relationships that form their environment.

According to this model, the microsystem is the small, immediate environment in which the child lives. The ecological model states that child development occurs within an interactive system of nested influences between the child and the environment. His ecological environment consists of the following five nested structures: microsystems, mesosystem, exosystem, macrosystem and chronosystem (Rathus, 2006:23; Berk, 2007:24; Donald, Lazarus and Lolwana, 2010). Children's microsystems will include any immediate relationships or organisations they interact with, such as their immediate family, school, peers, neighbours and caregivers. How these groups or organisations interact with the girl child will have an effect on how the child grows, the more encouraging and nurturing these relationships and places are, the better the child will be able to grow (Donald, Lazarus and Lolwana, 2010).

Bronfenbrenner's next level, the mesosystem describes how the different aspects of a girl child's microsystem work together for the sake of the child (Cole, Cole and Lightfoot, 2009). The exosystem level includes the other people and places that the child herself may not interact with often but still have a large effect on him, such as parents' work places, extended family members and the neighbourhood. (Bray, Gooskens, Khan, Moses and Seekings, 2010) describe the macrosystem as the one that involves dominant social and economic structures as well as values, beliefs and practices that influence all other social systems. The chronosystem involves development over time that affects the interactions between these systems as well as their influences on the academic and intellectual development of learners.

Given the above, understanding the interactions of these systems is therefore the key in understanding how the girls develop and what factors lead to their failure. While multiple environments and mechanisms exist, these researchers are interested in examining how poverty acts on families to influence academic achievement by focusing on five environments, which are family/home, neighbourhood, peers, school and government.

\section{Purpose of the Study}

This study seeks to explore the home based factors that militate against the academic performance of form three girl learners from poverty stricken households in Zimbabwe. It is guided by the following research questions:

- What are the home factors that mitigate against the academic performance of form three girl learners?

- What recommendations can be suggested to mitigate negative factors that do not promote the education of form three girl learners? 


\section{Methodology}

The main aim of the study was descriptive and exploratory.

\subsection{Research design and methodology}

According to Smith (2007), a research design refers to the plan and structure of the investigation used to obtain evidence to answer research questions. A good research is therefore not accidental. The qualitative phenomenological design was adopted for use in this study. It is good at surfacing deep issues and making voices heard (Creswell, 2010) and was thus found suitable to explore the home based factors that influence the education of girl children in Zimbabwe. It also allows the researcher to gain understanding of social phenomena from participants' perspectives in their natural settings (McMillan and Schumacher, 2010:315).

\subsection{Sampling}

The aim of sampling in social research is to produce representative selections of population elements (Cresswell, 2010). The study was carried out in two secondary schools in Masvingo district, Zimbabwe, one rural and another one urban. The participants comprised girl students doing form three (3) at the two secondary schools, their parents and also teachers teaching these pupils in nine different subjects. A sample of ten (10) girl learners, five (5) from each school, four teachers (4), two from each school and six (6) parents was purposively drawn.

\subsection{Data collection and analysis}

In addition to intensive review of related literature, data was collected through interviews, focus group discussions and observations with the participants comprising ten girl learners, six parents and four teachers. During the two focus group interviews with girl learners, the researchers created a social environment in which group members were stimulated by one another's perception and ideas. This technique was believed to increase the quality and richness of data, more than one-on-one interviewing could have done alone (McMillan and Schumacher, 2010:360).

An inductive approach to analysing the responses was undertaken to allow patterns, themes, and categories to emerge rather than being imposed prior to data collection and analysis. Similar responses were grouped together into categories. This identification of themes provided depth to the insights about understanding the individual views of the girls, their parents and teachers. Similar codes were aggregated together to form a major idea from the data (Cresswell, 2010: 256).

\subsection{Validation/ trustworthiness of data collected}

The interviews and focus groups were audio-taped and the researchers made observations and copious notes during the interviews. This strategy helped eliminate the problem of inaccuracy or incompleteness of the data which, according to Maxwell (2006:89) is the main threat to the valid description of what the researchers saw or heard. Information was obtained from individuals in their respective focus groups and settings, using different sources, cross checking and verifying sources of information (Cresswell, 2010).

\subsection{Ethical Considerations}

Permission to conduct the study was secured from Masvingo Provincial Education Office, Ministry of Education, Sports and Culture, Zimbabwe as well as from the selected school headmasters. Further permission was sought from the parents and guardians of the selected learners as well as from the selected teachers.

The participants were informed that their involvement in the study was voluntary and that they were free to withdraw at any stage of the interviews if they were not comfortable. Permission was first obtained from the participants for the interviews to be audio recorded. They were assured of anonymity in the research report.

\section{Findings and Discussion}

Findings and discussions were done in line with research questions. The analysis of the empirical data yielded the 
following themes, as shown by fig 1 below:

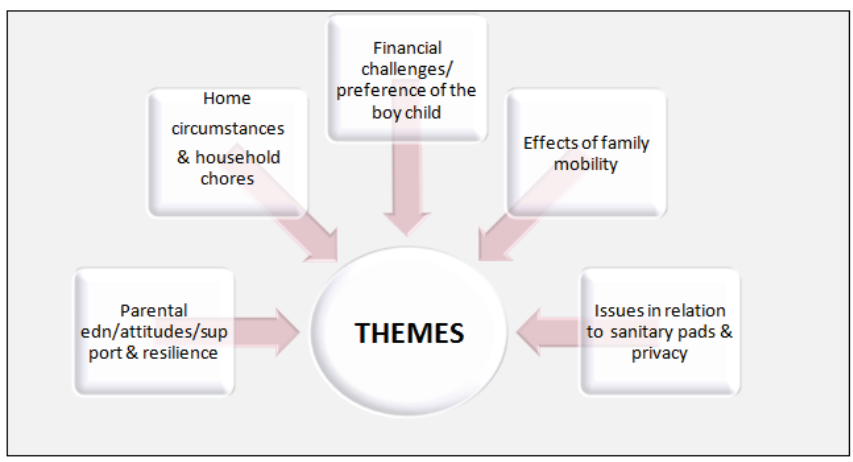

Fig. 1: showing themes for Home based factors affecting academic performance.

Source: Field data, 2013

\subsection{Parental level of education/attitudes/ support/ resilience}

The study established that poor girl students may face conditions in their homes that leave them with less time and energy for studies. This study established that poor girl students are likely to have parents, family members and neighbours who are also less educated. Such students are not able to get much guidance for their education in their homes. Much research has shown the importance of strong family-school relations (Parveen, Noor-UL-Amin, and Nazir, (2013). Threlfall, Seay, and Kohl, (2013); Hafiz, Tehsin, Malik, Muhammad, and Muhammad, (2013) point out that parents have a fundamental responsibility to ensure that their children are at school and their school work is done. However, these authors note, many parents have never attended school and they cannot read, write or count properly. Eneji, Ubom-Bassey, Eneji, Obogo and Dunnamah (2013) concurs with this when they state that children in rural areas and in poorer homes drop out earlier compared to their more affluent counterparts. The parents in this study purported that:

We do not have time or ability to help in homework of our children. We are incapacitated; we did not go to school ourselves. Sometimes we are too busy trying to make ends meet for our families. Time is also a serious challenge to us...it is the responsibility of the teachers to help students with homework since they are paid for that. Our responsibility as parents is to provide food on the table.

One parent seemed to sum the sentiments of the others when she stated that there were more pressing bread and butter issues to attend to than the school. Thus, poverty exerts much strain on parents who usually have different parenting styles, affected by stress and anxiety. During interviews, one teacher remarked that:

\footnotetext{
This situation may further get aggravated if they have only one parent or the parents are too busy to spend time with their children. Parents also engaged themselves in menial jobs, vending and temporary jobs which took too much of their time. As a result they could not supervise their children's homework thus exacerbating their academic pursuits. Parents from low income backgrounds have to deal with nonflexible work schedules and stress due to residing in disadvantaged neighbourhoods, which inhibits their involvement in their children's education.
}

This concurs with findings made by Donald, Lazarus and Lolwana, P. (2010). who assert that poverty is strongly correlated with a range of home background variables that affect academic performance. These home circumstances may also feature insecure or unstable environments often leading to emotional stress and school dropout among the girl learners. . Dixon-Roman, Everson and McArdle (2013) also point out that parental income and other indicators such as socio-economic status are related to various educational outcomes. This is supported by Otieno (2012) in a study conducted in Kenya. Manuel (2012) points out that poverty has major long term impacts on a child's development and that the debilitating effects of under nutrition last throughout the child's life. Poverty, these authors claim, is related to poor nutrition, learning disabilities, poor quality schooling and parental unemployment. Like rural schools and farm schools in South Africa, township schools are utilised by working class parents and a huge number of these families are poverty 
stricken. In support of the above, Berk (2007) in Chinyoka and Naidu (2013) also established that what happens in the family or peer group can influence how children respond at school and vice versa (mesosystem) thus lack of support from the family have negative impacts on cognitive development of girl learners.

Despite coming from poor backgrounds, some teachers noted that some girl students defied the odds and excelled in their academic performance. Other factors like resilience, inborn factors and family support and motivation come into play. Closely related to Bronfenbrenner's model, is Rutter's Pathway Model (Rutter, 2008:16), which endeavours to explain that children born in poverty can have self-righting tendencies, making them much more resilient to pressures of poverty. Because of the self-righting tendencies, some girl children end up believing that they are to remain poor, and so can be accustomed to poverty and live with it. In this study, some girl children, however, seem to cope well at school despite coming from poverty-stricken households and neighbourhoods. These children have resilience, and are able to accept their adversity and benefit from school whilst living in dire poverty. Resilience is an individual's capacity to recover from dysfunction and to rise above the disadvantage (Tugade, Fredrickson and Barrett, 2004). Children who have resilience tend to do better in some risky contexts when compared to children without protective factors in the same contexts; hence they excel in their school work. So, to say that all children from poor backgrounds and neighbourhoods will underperform at school, will be myopic, and an underestimation of a rather complex issue. There is therefore the need for researchers to explore the impact of resilience on the academic performance of girl learners from poor backgrounds.

From the foregoing discussion, the home has great influence on the student's psychological, emotional, social and economic state thus affecting academic performance. The importance of the home environment or family on girl learners' academic performance cannot be underestimated since the family is the source of basic inspiration (Bronfenbrenner, 2008). This indicates that parents have a role to play on the academic performance of their children. Parental attitudes towards school may lead to high or low level support they give to their children. In Zimbabwe, parents are responsible for assisting their children when doing homework. This simply means that the level of education of the parents affect the way they assist their children and this may have an adverse effect on the child's performance. The attitudes and behaviour of the significant others of the child such as parents, siblings, relatives and peers have been seen to affect the academic attitude of the girl child. These significant others are also the first socialising agents who affect how the girl child react to life situations and perceive academic achievement. Children from poor families have been in most cases seen to lack educational goals (Dixon-Roman, Everson and McArdle (2013). Broken families, single parent families and child headed families can be traumatic to children and usually children from such backgrounds may have emotional problems which may hinder good academic performance (Chindanya, 2012). Thus, the family background plays a pivotal role in building the character of the child and in enhancing academic performance.

\subsection{Home circumstances}

The study established that home circumstances are often not conducive to the learning of the girl children in the rural and urban communities studied. From the interviews with girl learners and their parents, it was revealed that girl learners live in large households ranging from six to fourteen. During interviews, G1 lamented that:

We are twelve in our family but our two bedroomed house can accommodate all of us. The only challenge we face is that of studying space especially in the evening. There is no privacy in the rooms.

This was reinforced by sentiments raised by some parents from both rural and urban areas. Those from urban areas remarked that:

Rentals are too high in Masvingo that we can only afford three rooms at most. We would rather be overcrowded than spending all our meagre salaries on rentals. If we spent all the money on rentals, where do we get money to buy food? A big spacious house is therefore not a priority.

A parent from the rural community, P5, also echoed the following sentiments:

Building materials are beyond the reach of many families in Zimbabwe. Very few families with an affluent background can afford building materials. This explains why we do not build big houses.

This clearly depicts that most of girls' respondents are members of large households. This can be attributed to the extended family relations, many children that characterised many households due to polygamy and very high rentals 
associated with urban households. The impact of large household size on the girl learner's education is that they did not have space to do their homework and study with their friends. In line with the above argument, the majority of the girl children from the two schools who participated in interviews and focus group discussions also posit that their studies at home were affected by lack of lighting, space to do homework, spending much time on domestic chores, having no desk or table to work on, an absence of books in the home, noisy neighbourhood and unsupportive parents.

Some of the statements expressing such views posited by girl students who participated in the two focus groups, FGD1 and FGD2 were that kumba kwakaomesesa, nokuti hakuna kana magetsi, macandles, tinoverenga nomoto (the situation at home is pathetic, we experience power cuts, our parents cannot afford candles and we sometimes use fire as light when writing homework.), tinorara muimba imwe tiri six (we live in crowded homes, sometimes more than six people share a bedroom), ...kumba kwedu kune basa rakawanda, hauzorori (we do not have time to rest because of various household chores) ...vabereki vedu havana kudzidza saka havagoni kutitisa basa rechikoro (Our parents are not educated therefore they fail to help us with the homework)...Takakombwa nemhuri dzinoita ruzha rwakawanda...(Our neighbours make a lot of noise, it is therefore difficult to concentrate on school work).

The FGD2 reveals that the low income workers in urban settings live in squashed and squalid conditions where the men mainly live with the children while the mothers are in the rural areas. The men drink beer everyday and play guitars in the compound leaving the children to all sorts of abuse with no one to look out for them because this is the nature of the society and at the end of the month, all the money goes towards paying for the beer debt.

This reinforces ideas brought forward by Bronfenbrenner (2008) who asserts that a lack of space, academic support at home, parents' inability to afford rentals and spacious homes constrain children's interaction with others leading to poor academic performance. Children in low-income families are reported to be less likely to spend time with their friends outside school compared with their more affluent peers. It is difficult for children to arrange social events. These home and school circumstances as alluded to by Bronfenbrenner's mesosystem may also feature insecure or unstable environments and financial insecurity, leading to anxiety and emotional stress (Chinyoka and Ganga, 2011). Ichado (1998) as cited in Ayodele and Adebiyi (2013) as well as Ekeke and Telu (2013) argue that the environment from which the learner comes can greatly influence her performance academically in the school. This therefore can have a bearing on the psychosocial development of the girl child in Zimbabwe.

The problem of limited space in this study is observed to be compounded by low income. The teachers and parents interviewed established that children who experience poverty live in physical environments that offer less stimulation and fewer resources for learning. During interviews, one teacher, T4 said:

Many poor girl children begin life at a disadvantage, due to low family income, low maternal education, single parents, poor parents, poor and noisy neighbourhoods, poor houses, unsupportive parents, lack of resources or a combination of these factors.

\title{
A parent, $\mathrm{P} 2$, interviewed in this study also posited that:
}

\begin{abstract}
Absenteeism, ill health, malnutrition, hunger and other elements of children from poor families may be militating against their growth and achievement in school because of unstable incomes of their parents.
\end{abstract}

This confirms also what was said by all the four teachers during interviews, who chronicled that pupils from homes with better quality houses, who always spoke English at home, had most learning materials, who ate at least three meals per day, who had many possessions and more educated parents achieved better in school. It should also be noted that if the home environment, for example, is not supportive, without media, television, magazines and helpful parents, children suffer from a restricted code and therefore will not perform well (Bernstein, 1990 cited in Haralambos and Holborn, 2010). According to the ecological theory, if the relationships in the immediate microsystem break down, the child will not have the tools to explore other parts of her environment. This is also supported by Chindanya (2012) who asserts that instability and unpredictability of family life is the most destructive force of the child's development.

Given the above, ideally the environment in which the children under this study live fell far short of what Cameron, (2012); Donald, Lazarus and Lolwana, (2010); Chinyoka and Naidu, (2013); Bronfenbrenner, (2008) prescribed for as a conducive learning environment. Children reported that because of a shortage of space, overcrowding and not having any privacy or room to be alone, causes arguments and tension, thus affecting family relationships, which in turn affect academic performance. A vicious cycle of poverty can be noted when poor children, live in poor accommodation, attend poor schools and are taught by inexperienced teachers with a low self-esteem and a low self-concept.

The study found out that the girls are losing out on education because they are needed more to support their household with labour. This writers and some teachers, $\mathrm{T} 1, \mathrm{~T} 2$ and $\mathrm{T} 3$ observed that the situation was rather unbearable 
in child headed households where there is no mother to whom burdens may be shifted. Three parents interviewed, also revealed that the older girl child in most cases are observed to take the role of the mother as she struggles to make ends meet in all efforts to resemble the mother within the child headed household. The situation reflects the circumstances discussed by Lacour and Tissington (2011). This is also observed in a study done by Otieno (2012) in Kenya. The voices of girls below during interviews and focus group discussions explain some of the challenges that they faced at home and how they affected their participation in school:

Pamba pakawoma. Basa racho haritomboperi. Unoshanda zvokuti kuchikoro mamwe mazuva hautomboendi. (The situation at home disadvantage us. There is too much work to do. Sometimes we do not go to school because of pressure of work)

As girls we are given so much work at home such that we cannot read. We do all the household chores like washing clothes, cleaning the house, feeding young ones, looking after sick relatives and parents, cooking for the entire family, fetching firewood and water before we go to school. We also sell vegetables, fruits, juice cards and sometimes our bodies to supplement family income. We do not have time to study and to do our homework.

A girl learner from a child headed household in Mapanzure communal area also lamented that:

There is too much pressure from taking household responsibilities which even a much older person may not be able to handle. My academic performance is sometimes affected by unnecessary mistakes, loss of focus in class and lack of concentration due to too much stress from home.

Another girl from the rural setting, $\mathrm{G} 3$ shared that:

I had to wake up as early as 4.00 am to water our garden which is about $1 \mathrm{~km}$ away. I fetch water from a long distance, I don't enjoy this. It's terrible when menstruating because I have 'jeko' (abdominal pains associated with menstruation)... By the time I reached class I will be so tired and in a lot of pain. I have difficulties in concentrating in class and indeed I didn't learn anything that day.

The teachers, T1, T2, T3 and T4 also noted that the girls were exposed to too much work by their parents thus they did not have time to study and to do their homework thus negatively affecting their academic performance. In agreement, Chinyoka and Naidu (2013) also posits that when girls or women try to combine schooling with home apprenticeship, the choice between work time and study time may lead to family tensions, poor performance, poor lesson attendance and dropouts. The above also confirms the research by Okeke, Nzewi and Njoku (2012) that concluded that higher priority is placed on girls' domestic workload than their academic performance. Given the above, it is reasonable to conclude that poor performance and constant absenteeism are fuelled by such/all variables mentioned above because they lead to girls repeating class which in turn kills their self-esteem and confidence and may eventually drop out. Although these challenges affect the rural children most, the situation is not so different from what happens in the urban poor settings. Thus, Bronfenbrenner (2008) urges educators to establish and maintain family-school dyadic relationships in order to enhance pupils learning. Without education, girls are denied the opportunity to develop their full potential; hence they will fail to self-actualise as proposed by Rogers and Maslow, thus affecting their self-esteem, self-concepts and academic performance (O'Neil, 2011). This finding agree with Hlupo and Tsikira (2012) who observed that a student who participates in tedious or much work at home may spend little time on school work leading to poor performance.

The long hours children must work impair their intellectual development. It is unreasonable to think that children can learn while they are physically exhausted and mentally tired. This study established that for many girl children, hours spent in school become a time for resting, not for learning. Since girls are responsible for the vast majority of household chores, little time is set aside for school and homework. When the two become too much to handle, Chinyoka and Ganga (2011) observed that schooling was the last priority. The time they spend doing household chores disadvantages them and affects their performance. Access to the library, group discussions and actual reading or study time is greatly reduced as a result. The study also noted that when they got that little time to read, they were so tired that their concentration span was affected and also retention, attention, motor reproduction skills, motivation and academic performance.

\subsection{Financial challenges/Preference of the boy child}

Results from both the interviews and the two focus group discussions established that the direct and indirect costs of education are considered to be the major barriers in accessing secondary education for girls in the two schools studied. 
This study established that the financial costs of schooling are often high, making it difficult for poor parents to afford schooling for their girl children. The girls interviewed and who participated in the focus group discussions disclosed that:

The financial costs included not only school fees, but also other indirect costs, such as the costs of food, transport, writing paper/exercise books, textbooks, pens, sanitary pads, pocket money, and school uniforms.

The researchers observed that the monetary costs of schooling continue to dominate the reasons for the drop-out of girl learners in the rural and urban schools studied. The majority of the Form 3 girl learners from the rural secondary school who participated in this study indicated that poor households sometimes saw investing in girl's education as not worthwhile as it is expected that daughters leave their homes upon marriage. One of the girls who were interviewed and who participated in the focus group discussions remarked that:

\begin{abstract}
Many parents see the benefits of educating boys as more tangible and economic, saying that the majority of the parents think boys are a better investment; hence girls should remain at home to help with all the domestic chores and bear children.
\end{abstract}

The teachers and parents who were interviewed agreed, also revealing that some parents in the Mapanzure communal area were sceptical to educating the girl child, since it is seen as a waste of the family's resources. In some communities gender bias starts from birth, where a son's birth brings happiness to the parents, and girls are seen as a stigma on the family. Primitive as this might sound, Hlupo and Tsikira (2012) confirm that high education costs have seen the male child receiving preference to continue with his education. In line with the above argument, UNESCO (2010:19) posits that educating daughters is seen as a monetary loss, thus parents prefer to educate their sons rather than their daughters. Further, the Integrated Regional Information Networks (2011:1) also states that the Education, Sports, Arts and Culture Minister, Senator David Coltart, said that over $50 \%$ of young girls meant to go for secondary education in Zimbabwe were forced to drop out because of various reasons, the main being the unavailability of funds, and the society's preference to educate the girl child.

Implicit to the above, gender bias and the unavailability of resources, among the other determinants of academic performance, have taken their toll on the girl child's education. This bias for the sons' education is based on the notion of economic returns, where sons are seen as money-makers for the family. As the girls have to go to the other family after marriage, the parents sometimes preferred the dowry to the girl's education. The researchers can therefore conclude that cultural reasoning and gender biased ideologies, marginalisation and stereotyping come to play in disadvantaging the girl child in her pursuit of education in the two schools studied. It should also be noted that the existing cultural expectations, norms and values also influence the pattern of girls' participation in formal education.

\title{
5.4 Effects of family mobility
}

Findings from interviews reveal that children from poor backgrounds move from town to town, village to village and school to school as their parents search for work or run around to make ends meet. Changes in residence and the frequency of those moves were observed in this study to impact family dynamics due to disruptions in social support. During interviews a teacher from the urban secondary highlighted that:

\begin{abstract}
The girl children are forced to move with their parents making drop out of school temporarily or permanently. The school attendance is often irregular amongst children whose parents are very mobile hence transfer to a new school becomes the norm. Moving often forbids the students from developing consistency in their lives.
\end{abstract}

This collaborates the researches done by Bee and Boyd (2007); Bronfenbrenner, (2006; 2008) who posit that mobility also compounds the difficulty these children have in making friends thus manifesting their problems by acting out, exhibiting aggression, depression, regressive behaviour, inattentiveness, and anxiety. All these were observed to have a negative impact on the academic performance of the girl child.

The teachers interviewed reported that the girl children whose parents are very mobile often come to school with no records from their previous schools; and it may be difficult for schools to track the records down. Teachers have no idea what these students have learned. One teacher, T3, says:

Even if placement is successful, these children will be likely to move again within the school year, making them difficult to teach. They lose a lot of valuable teaching and contact time... It is also challenging to help these students to learn at least something of value while they remain in their classrooms because of their high mobility. The mobile learners show 
all signs of stress which hinder their academic performance. Stress makes the brain fail to assimilate and accommodate taught and learnt information.

Given the above, constant changes in schools by learners affect them in many ways which affect their academic performance. This reinforces findings made by Conger and Donnellan (2007) as well as Engle and Black (2008), who also established that frequent change of schools by the learners is detrimental to their academic performance. It is therefore challenging for schools to place these children in classrooms and get them additional services they may need. Combining this issue with the multitude of other issues faced by mobile and homeless children and the impact on their emotional, social and cognitive development can be overwhelming (Bronfenbrenner, 2008).

\subsection{Issues in respect of sanitary pads and privacy}

The results from the interviews and focus group discussions also revealed that for the majority of the Form 3 girls who have reached puberty, there is also the added cost of sanitary pads during menstruation. The girl learners who participated in the two focus group discussions also echoed the following sentiments, namely,

During menstruation, our families cannot afford sanitary pads. They are expensive; we are therefore forced to use tissue paper, newspapers, plastic papers, papers from exercise books, leaves and rags instead.

In concurrence G2, G4 and G3, all from the rural secondary school and G6 and G8, from the urban secondary school, reported to have to make use of papers from old books, tissues, newspapers and rags as protection, and this made them feel very uncomfortable in class. The above observations confirm the findings of Burrows and Maunder (2004: 14) who posit that the lack of adequate water and sanitation, both at home and at school, prevented menstruating girls from attending school when menstruating. Given the sentiments echoed by the girl participants in this study, these problems associated with menstruation and poverty negatively influence the girls' schooling, thus causing lower completion and poor attendance rates, culminating in poor academic performance. It should be noted that menstruation and its accompanying physical, psychological and hygiene requirements therefore have implications for the girl child's participation in education as regards access, retention, attendance, and the final completion of a grade.

\section{Conclusions / Recommendations}

This study focused on some home based factors that influence the girl child's academic performance. The girls require a good environment, which is conducive to learning. They should be supported by their families by providing good lighting systems, enough reading space, and minimal interference from family members or friends when doing their homework. Family characteristics like socio economic status (SES), parental and family support are also significant predictors for students' performance at school. Parental education and occupation also have effects on students' academic performance. Girl students' from poor families lack basic items such as food, sanitary pads, textbooks, exercise books, pens, pencils and school fees and this adversely affect their participation in education. The academic achievement of girl students' is also affected to a greater extent by the family mobility, household chores and family/household size.

Finally, the government should sensitize parents on the need and importance of supporting girl education for better performance. Family life programs should focus on encouraging families not to exceed five children and place emphasis on one to three children as the ideal family size for people living above poverty line. Every effort must be made to ensure that the affected children have stable, preferably, home/family based care and adequate social support. Various government policies and interventions can help to attenuate poverty's negative influence especially on the girl child development.

\section{References}

Ayodele, C.S., \& Adebiyi, D.R. (2013). Study habits as influence of academic performance of university undergraduates in Nigeria. Research journal in organizational Psychology \& Educational studies, 2(3) 72-75.

Bee, H., \& Boyd, B. (2007). The Developing Child (11th ed.) Boston, MA: Pearson.

Berk, L. E. (2007). Development throughout the lifespan, Needham Heights: Allyn and Bacon.

Bray, R., Gooskens, L., Moses, S., \& Seekings, J. (2010). Growing up in the new South Africa: Childhood and adolescence in post apartheid Cape Town: HSRC press.

Bronfenbrenner, U. (2006). Ecology of the family as a context for human development: Research perspectives. Developmental Psychology, 22(6), 723-742. 
Bronfenbrenner, U. (2008). Ecology of human development. Cambridge MA: Harvard University Press.

Brooks-Gunn, J., Duncan, G.J., \& Aber, J.L. (2007). Neighbourhood Poverty, Context and Consequences for Children. New York: Russell Sage. Burrows, G.J.A., \& Maunder, T. (2004). Water and sanitation: the education drain. London:Sage.

Cameron, S. (2012). Education, urban poverty and migration: Evidence from Bangladesh and Vietnam. Working Paper 2012- 2015. UNICEF Office of Research, Florence.

Chabaya, O., Rembe, S., \& Wadesango, N. (2009). The persistence of gender inequality in Zimbabwe: Centre. Paris: Organisation for Economic Cooperation and Development.

Chindanya, A. (2012). Effects of parental involvement in the education of children. Unpublished D.Ed. thesis. Pretoria: UNISA.

Chinyoka, K., \& Naidu, N. (2013). Uncaging the Caged: Exploring the Impact of Poverty on the Academic Performance of Form Three Learners in Zimbabwe. International Journal of Educational Sciences, 6, 203- 213.

Chinyoka, K., \& Ganga, E. (2011). An Exploration of Psychological Effects of Poverty on Child Development in Ngundu in Zimbabwe. NAWA Journal of Language and Communication, 4 (1), 154-178.

Cole, M., Cole, S., \& Lightfoot, C. (2009). The Development of Children. New York: Worth Publishers

Conger, R.D., \& Donnellan, B. (2007). An interactionist perspective on the socioeconomic context of human development . Annual Review of Psychology, 58, 175-199.

Creswell, J.W. (2010). Research Design: Qualitative, Quantitative and Mixed Methods Approaches (Third Edition): London. Sage publications.

Dixon-Roman, E.J., Everson, H.T., \& McArdle, J.J. (2013). Race, poverty and SAT scores: Modeling the influences of family income on Black and White High School students' SAT performance. Teachers College Record, 115(4), 1-10.

Donald, D., Lazarus, S., \& Lolwana, P. (2010). Educational Psychology in Social Context Ecosystem Applications in Southern Africa. Cape Town: Oxford University Press.

Ekeke, H., \& Telu, J. (2013) Influence of home on study habits of seconday school students in Kolo- Creek development centre of Bayelsa State, Nigeria. American journal of secondary education, 1(1) 1-6.

Eneji, C.V.O., Ubom-Bassey A.E., Eneji, J.E.O., Obogo, G.O., \& Dunnamah, A.Y. (2013). Influence of family types and parent's socio-economic status on school dropout among female students in Old Ogoja Zone of Cross River, Nigeria. GARJAH, 2(1), 7-13.

Engle, P.L., \& Black, M.M. (2008). The effect of poverty on child development and educational outcomes. Annuals of the New York Academy of Sciences, 1136, 243-256

Ganga, E., \& Chinyoka, K. (2010). Psychological Disorders caused by Poverty among Orphans and Vulnerable Children in Child Headed Households in Zimbabwe, Journal of Sustainable Development in Africa,12(4),186-198.

Haralambos, M., \& Holborn, M. (2010). Sociology Themes and Perspective. London: Collins Educational.

Hlupo, T., \& Tsikira, J. (2012). Still caught up in cultural abyss: The plight of the girl child. Journal of Emerging Trends in Educational Research and Policy Studies (JETERAPS), 3(3), 44-49.

Integrated Regional Information Networks, (2011). Zimbabwe: Thousands of girls forced out of education. Zimbabwe girl child dropout figures reach alarming levels. [Online\}Available http. //www.com/bookmark.php.plusnews (15 November, 2013).

Kaur, J. (2013). Parental encouragement as a predictor of academic achievement of college students. Quest International multidisciplinary research journal, II(I), 5-7. [Online]. Available www.mahidachintan,com. (Accessed on 17 December 2013).

Korenman, S., Miller, J., \& Sjaastad, J. (2005). Long-term poverty and child development in the United States: Results from the National Longitudinal Survey of Youth. Children and Youth Services Review, 17 (1), 127-155.

Lacour, M., \& Tissington, L.D. (2011). The Effects of Poverty on Academic Achievement. Educational Research and Reviews Journal, 6 (7), $522-$ 527.

Manuel, T. (2012). Reflection on child poverty and inequality. South African Child Gauge, 10-11.

Modisaotsile, B.M. (2012). The failing standard of basic education in South Africa. Policy Brief, AISA, 72, 1-7.

Maxwell, J.A. (2006). Qualitative Research Design: An interactive approach. Thousand Oaks: SAGE Publications.

McMillan, J.H., \& Schumacher, S.S. (2010). Research in education: evidence-based inquiry. (6 $6^{\text {th }}$ ed.). Boston: Pearson.

Okeke, E.A.C., Nzewi, U.M., \& Njoku, Z. (2012). Tracking school age children's education status in UNICEF A-Field states. Lagos: UNICEF.

O’Neil, V. (2011). Psychology: An introduction. (3rd ed.). Cape Town: Oxford University Press.

Otieno, T.A. (2012). Home based factors influencing girls' performance at Kenya certificate of Secondary education in Nyatike district, Kenya. [Online] Accessed http://erepository.uonbi.ac.ke:8080/xmlui/handle/123456789/7037. (17 December 2013).

Parveen, A., Noor-UL-Amin, S., \& Nazir, S.K. (2013). Comparative study of the academic achievement of $10^{\text {th }}$ class boys studying in different high schools of District Pulwams of (J\&K). Journal of Education Research and Behavioral Sciences, 2(2), 20-27.[Online] Available at http://www.apexjournal.org/JERBS. (Accessed on 10 December 2013).

Hafiz, H.M.W., Tehsin, F., Malik, M.S., Muhammad, S., \& Muhammad, A.K. (2013). Parental involvement and academic achievement: A study on secondary school students of Lahore, Pakistan, International journal of Humanities and Social Science, 3(8), 209-223.

Rathus, S.A. (2006). Childhood: Voyages in Development, California: Thomson Wadsworth.

Rutter, M. (2008). Developing concepts in developmental psychopathology. In: JJ. Hudziak (ed.), Developmental psychopathology and wellness: Genetic and environmental influences. Washington, DC: American Psychiatric.

Smith, J.A. (2007). Hermeneutics, Human Sciences and Health: Linking Theory and practice. International Journal of Qualitative Studies, 2, 3-11.

Threlfall, J,M., Seay, K.D., \& Kohl, P.L. (2013). The parenting role of African-American fathers in the context of urban poverty, Journal of Children and Poverty, 19(1), 45-61.

Tugade, M.M., Fredrickson, B.L., \& Barrett, L.F. (2004). Psychological resilience and positive emotional granularity: Examining the benefits of positive emotions on coping and health. Journal of Personality, 72(6), 1161-1190.

Woolley, M.E., \& Kaylor, A.G. (2006). Protective family factors in the context of neighbourhood: Promoting positive school outcomes. Family relations, 55(2), 93-104. 